\title{
The Impact of Translation Techniques on Politeness Strategies in Giving Advice
}

\author{
Havid Ardi \\ Faculty of Languages and Arts \\ Universitas Negeri Padang \\ J1. Prof. Dr. Hamka, Padang, Indonesia \\ havid_a@fbs.unp.ac.id \\ Djatmika \\ Faculty of Cultural Sciences \\ Universitas Sebelas Maret \\ J1. Ir. Sutami, Surakarta, Indonesia \\ djatmika@staff.uns.ac.id
}

\author{
M. R. Nababan \\ Faculty of Cultural Sciences \\ Universitas Sebelas Maret \\ Jl. Ir. Sutami, Surakarta, Indonesia \\ amantaradja@gmail.com \\ Riyadi Santosa \\ Faculty of Cultural Sciences \\ Universitas Sebelas Maret \\ J1. Ir. Sutami, Surakarta, Indonesia \\ riyadisantosa@staff.uns.ac.id
}

\begin{abstract}
Giving advice is a common speech act but potentially problematic as it may threaten the face of the hearer. The speaker will use politeness strategies to mitigate face threatening act in giving advice. Politeness strategies as mitigation are not only appeared in real conversation but also in fiction. Thus it raises a question how translators deal with politeness marker in giving advice in intercultural context. This paper aims at exploring the translation of politeness markers in giving advice used by the main characters in the novel Deception Point written by Dan Brown (2001). Data were the utterance of advices made by main characters in the novel Deception Point and its two Indonesian translation version. Data were taken by document analysis and focus group discussion in classifying the translation techniques. The result show that 1) there are only two main characters who give advice due to the felicity conditions of advice, 2) positive and negative politeness strategies are employed by the main characters in giving advice, 3 ) there is a change in the translation caused by the implementation of translation techniques to the politeness markers.
\end{abstract}

Keywords-advice; politeness strategies; politeness marker; translation; technique

\section{INTRODUCTION}

Giving advice is a common speech act used in daily live. However, this act potentially problematic as it may threaten the face of the hearer. Leech defines that giving an advice means proposing a course of action to be taken by Other (Leech, 2014, p. 204). Giving advice is one of directive acts that aim other to do certain thing based on the speaker's utterance. To anticipate threatening the hearer's face, the speaker will use politeness strategies in giving advice.

Brown and Levinson propose that there are at least 5 super strategies used by the speaker in mitigating the face threatening act (P. Brown \& Levinson, 1987), they are bald on record, positive politeness, negative politeness, off record, or just keep silent. However, each language related to its culture may have its own politeness strategies that are considered as a polite way (Kecskes, 2015).

Studies of politeness markers in speech acts has been studied by some researchers, such as, request (Leech, 2014), command in literary work (Zhao, 2009; Umalee, 2013; Ardi, Nababan, Djatmika, \& Santosa, 2018), command in film subtitle film (Pratama, 2014; Mubin, 2015), advice-giving (Gaffney, 2015; Silence, 2013), computer-mediated environment (Kouper, 2010; Adel, Davoudi, \& Ramezanzadeh, 2016), and in the translation text (Tretyakova, 2016; Ardi, Nababan, Djatmika, \& Santosa, 2016a; 2016b; 2018). However, those studies were focused real communication and monolog setting, and do not yet discuss politeness strategies employed in giving advice in the translation which includes intercultural pragmatic related to the norm of source and target languages. Moreover, lack of research exposes the analysis on the translation of advice.

Moreover, Kecskes (2015) finds that the politeness strategies may work differently in different culture. For, instance, addressing father by using his name maybe acceptable in a certain culture, however it is not acceptable in Indonesian culture (Ardi, et al, 2016a). For instance, in the novel "To Kill the Mockingbird" a son called his father by using his name, Atticus. It is translated by using borrowing technique in the translation text. It can be said as transference of source language culture; however it is unacceptable in the target language. Thus it may create a problem in translation.

Moreover, politeness strategies are not only used in real live conversation. In fiction, the characters are described indirectly about how they talk and interact with other characters (Minderop, 2011; Chaghervand \& Toroghpeima, 2015). Since each culture has its own way of politeness strategies, it raises a question how translators deal with politeness marker in giving advice in intercultural context.

This paper aims at exploring the translation of politeness markers in giving advice used by the main characters in the 
novel Deception Point written by Dan Brown (2001). The paper has three research question, they are: 1) what characters and what politeness strategies used in giving advice in the in the novel Deception Point; 2) how advice-giving utterances and politeness markers are translated in the two versions of Indonesian translation?, 3) what are the impact of translation techniques to the utterance?

\section{LITERATURE REVIEW}

\section{A. Directive Acts, Advice, \& Politeness}

Directive acts are the speech acts which have high face threatening act (FTA) toward the hearer since the illocutionary force is to ask other to do something for the speaker (Cutting, 2008 , p. 15). One of the directive acts is advice. In analyzing of advice as a speech event, we have to pay attention to concept of advice. The speech act with advice illocution is like suggestions. Both of these speech acts belong to directive act. Leech (2014) put suggestion similar advice. Actually, whenever they are compared, suggestion and advice are not interchangeable.

Advice is defined as "opinions or counsel given by people who perceive themselves as knowledgeable, and/or who the advice seeker may think are credible, trustworthy and reliable" (DeCapua \& Dunham, 1993). This definition limits the people who can give advice. Meanwhile, suggestion can be said as a speech event that the action is to be performed by both Speaker $(\mathrm{S})$ and Hearer $(\mathrm{H})$, for the benefit of both. For example, the suggestion "Let's go to the movies" as is performed by speaker and hearer. There is also a kind of Sfocused suggestion that is more like a tentative offer (since the action is to be performed by S). Whereas, advising is an utterance for the benefits is only for the hearer and to be performed by the hearer only (Leech, 2014, p. 137). Therefore, the distinction between advice and advice lies in who does and for whom.

Furthermore, suggestion and advice can also be distinguished from the authority or power (age and experience) that the speaker has. Suggestions may be given by speakers to higher-level social hearer. In contrast, advice is a directive act delivered for the benefit of the hearer (Leech, 2014 , p. 204) but the speaker has higher authority over the hearer, that can be related to the knowledge, and or experience thus the speaker is trustworthy.

Since advice-giving potentially threat the hearer's face, the speaker should choose the appropriate politeness strategies to mitigate the impact of FTA in giving advice to the hearer. The selection of politeness strategy is also affected by the context of situation between the speaker and hearer. Brown \& Levinson (1987) say that the selection strategy is affected by the position (power/P), within the proximity of the speaker and the hearer (distance/D), and the rank of imposition (R).

Politeness studies were started by some scholars such as, Lakoff in 1973. Then, it is described by Brown dan Levinson in 1978 (1987), Leech in 1983 (2014), and Blum-Kulka. Lakoff introduce politeness as interpersonal relation system that was designed to enhance interaction by minimizing conflict and confrontation potential that might be happened in human interaction (Lakoff, 1973). Lakoff relates politeness and Cooperative Principles proposed by Grice. Grice states that principally people are cooperative and aimed at giving information as much as possible in the communication, but it frequently violates the cooperative principle (Brown \& Levinson, 1987). This cooperative principle is combined with politeness theory that in the communication the speaker will try to speak clearly to avoid misunderstanding by employing politeness strategy.

There are some models in analyzing politeness category proposed by the experts. Leech in 1983 (2014) proposed six principles of politeness, they are: tact maxim, generosity maxim, approbation maxim, modesty maxim, agreement maxim, and sympathy maxim. This principle is based on cost and benefit between speaker and hearer. Then, Brown \& Levinson (1987) classify that the speaker will probably choose five strategies for politeness, they, bald on record strategy, positive politeness, negative politeness, off record strategy, and keep silent. This model is based on face concept (Brown \& Levinson, 1987).

In this paper politeness strategies employed in giving advice by the speakers (main characters in the novel) are classified based on the theory of Brown \& Levinson (1987). The classification is, bald on record, positive politeness, negative politeness, and off record strategy. This category is chosen since it

\section{B. Translation Techniques}

Translation technique is defined as a way implemented in solving translation problems in the translation text. Many translation scholars used various and different term for this phenomenon, such as, translation procedure (Newmark, 1988), translation strategies (Machali, 2009; Baker, 2018). In the translation process, translators employ various strategies to solve the translation problems. Strategies are the ways to find a suitable solution for a translation unit. The solution will be materialized by using a particular technique (Molina \& Albir, 2002). Therefore, translation strategies are part of the translation process, and translation techniques employed in the translation text (Molina \& Albir, 2002).

The classification of translation techniques in this paper is classified based on the classification proposed by Molina \& Albir (2002) and added with other category which is not implemented by Molina \& Albir.

\section{METHOD}

This was qualitative research. Source of data were the novel Deception Point written by Dan Brown (2001) as a source text, and the two Indonesian translation version issued in (2006) translated by Isma B. Koesalamwardi and Hendry M. Tanaja published by PT Serambi Ilmu Semesta (Jakarta) and the second version issued in (2015) translated by Dwijani Nimpoena published by PT Bentang Pustaka (Yogyakarta) as target texts. Data were the utterance of advice made by main characters in the novel Deception Point in the source text and the translation of the utterances in the two Indonesian translation versions in the target texts. The data of utterances were collected from seven main characters, they are Gabriele Ashe (GA), Marjorie Tench (MjT), Rachel Sexton (RS), Sedgewick Sexton (SS), Michael Tolland (MT), William 
Pickering (WP), and Zachary Herney (ZH) as participants in the media. Data were taken by document analysis and focus group discussion in classifying the translation techniques. Data were analyzed by domain, taxonomy, and componential analysis (Spradley, 1980; Santosa, 2017).

\section{RESUlT AND DisCUSSION}

Based on the felicity condition of advice, there are limited characters that produce advice. The frequency of occurrence is relatively small (10 data) on the Source Text (ST) because not many utterances that meet the criteria. For details, the following explanation shows the result of the result.

\section{A. Characters and Politeness Strategies used in Giving Advice in the Deception Point Novel}

This research focuses on the utterances expressed by the seven main characters in the novel Deception Point. After conducting document analysis, it was found there are only two characters that produced advice to others. Based on the analysis number of advice found in the source text performed by the main characters are shown in table I.

TABLE I. FREQUENCY OF ADVICE BY MAIN CHARACTERS

\begin{tabular}{|l|r|r|r|r|r|}
\hline \multicolumn{3}{|c|}{ Advice } & \multicolumn{5}{c|}{ Strategy in the Source Text } \\
\hline \multicolumn{1}{|c|}{ Speaker } & Freq. & \multicolumn{1}{c|}{ BOR } & \multicolumn{1}{c|}{ P } & \multicolumn{1}{c|}{ N } & \multicolumn{1}{c|}{ O } \\
\hline GA & - & - & - & - & - \\
\hline MjT & - & - & - & - & - \\
\hline RS & - & - & - & - & - \\
\hline SS & 7 & - & 8 & 3 & - \\
\hline MT & - & - & - & - & - \\
\hline WP & 3 & - & 4 & - & - \\
\hline ZH & - & - & - & - & - \\
\hline Total & 10 & - & 12 & 3 & - \\
\hline Percentage & & - & 80.0 & 20.0 & - \\
\hline
\end{tabular}

a. BOR: Bald on record; P: Positive politeness, N: Negative politeness, O: Off record strategy

Table I shows that there are only three characters produced advices; they are Senator Sedgewick Sexton (SS) and William Pickering as the Director of NRO. Related to their power, both characters have higher position. On the other hand, the character Zachary Herney $(\mathrm{ZH})$ although he has higher position as president, he does not produce any advice but mostly suggestion.

Moreover, Table I shows that mostly the speakers or characters used positive politeness strategy in this novel. There is $80 \%$ positive politeness markers employed in the utterance in giving advice and there is only $20 \%$ negative markers employed. It means, the characters choose to show their closeness or attend hearer positive face.

As mentioned by Leech $(2014$, p. 137) advice is a directive delivered for the benefit of the hearer (Leech, 2014, p. 204) but the speaker has authority over the hearer, in term of power, knowledge, etc. That is why only small number of characters who produced advices. Meanwhile, GA, RS, MT, and MjT are characters that have lower position if they are compared to $\mathrm{ZH}$, SS, and WP. Moreover, table I shows that SS produced more advices than WP. The utterances of advice performed by $\mathrm{SS}$ are given to his daughter, RS. This advice is told to RS to think about her life to get married as shown in example 1.

\author{
Example 1/SS-RS \\ ST : “Think about your future, Rachel. You can \\ come work for me." (20)
}

Data above show that SS used positive politeness strategy by using in-group identity marker. SS mentions the name of the hearer, Rachel (Brown \& Levinson, 1987, p. 107). This strategy indicates speaker know the hearer well.

The second Example shows advice produced by SS to RS to perform good attitude at the other.

\section{Example 2/SS-RS \\ ST : "You'd do well to learn some poise." (24)}

This advice is told to RS to be more polite to other people and able to control his emotions. He use obligatory marker "would" as the highest obligatory (Leech, 2014, p. 148) and hedges that strengthen the imposition "do" (Brown \& Levinson, 1987). It is because he is a little bit angry to his daughter who disregards his campaign as president candidate and he has the capacity for good thing according to his experience.

The third Example is an advice given by SS to RS to get married.

\section{Example 3/SS-RS \\ ST : "And get married, for God's sake. You're thirty-three years old." (24)}

SS reminds his daughter to think about her future and get married soon. To mitigate the advice, SS employed negative politeness by using "for God's sake" as an exclamatory expression. Actually, it is quite risky to give advice about getting married that is why SS used negative politeness strategies to minimize the FTA.

The last Example was an advice produced by WP to RS. WP is the director of NRO where RS works.

\section{Example 4/WP-RS}

ST : He gave her a stern stare. "A word of warning, Agent Sexton. If you feel that your personal issues with your father are going to cloud your judgment in dealing with the President, I strongly advise that you decline the President's request for a meeting." (32)

This advice was given to RS before she accept the request from the president to have a meeting. Since his father (SS) and the president $(\mathrm{ZH})$ are candidates for the president, WP gives an advice to avoid conflict of interest if RS attend the meeting. WP used positive politeness strategy by using exaggeration "strongly".

Based on the example above, the characters tend to show their relationship in giving advice. It functions to mitigate face-threatening act. Mostly the utterances of advice given by SS were live or personal experience, meanwhile WP gave professional advice. This finding is in line with Silence (2013) and (Adel, Davoudi, \& Ramezanzadeh, 2016) who also discover that positive politeness strategies are frequently used 
in giving advice in professional and education sector. The next question is how those politeness markers translated into the target language? The next finding reflects how the characters employed politeness strategies in the target language.

\section{B. The Translation of Advice-giving Utterance \& Politeness Markers in the Two Indonesian Translated Versions}

The result of translation of the advice-giving utterance and politeness markers from English into the Indonesian translation text can be shown in the table II. The number of positive politeness marker is increased in both target texts.

TABLE II. FREQUENCY OF POLITENESS MARKERS IN EACH TEXT

\begin{tabular}{|c|c|c|c|c|c|c|c|c|c|c|c|c|c|}
\hline \multirow{2}{*}{ Utter } & \multirow{2}{*}{ Fre } & \multicolumn{4}{|c|}{ ST } & \multicolumn{4}{|c|}{ TT1 } & \multicolumn{4}{c|}{ TT2 } \\
\cline { 3 - 14 } & & $\mathrm{B}$ & $\mathrm{P}$ & $\mathrm{N}$ & $\mathrm{O}$ & $\mathrm{B}$ & $\mathrm{P}$ & $\mathrm{N}$ & $\mathrm{O}$ & $\mathrm{B}$ & $\mathrm{P}$ & $\mathrm{N}$ & $\mathrm{O}$ \\
\hline Advi & 10 & - & 12 & 3 & - & - & 15 & 2 & - & - & 13 & 3 & - \\
\hline & & & $80 \%$ & $20 \%$ & & & 88,2 & 11,8 & & & 81,2 & 18,8 & \\
\hline
\end{tabular}

TT1 has 15 positive politeness markers while TT1 has 13 politeness markers. Meanwhile, the number of negative markers is reduced in TT1. It indicates that translators tend to add positive markers in the target text.

Based on the comparison between ST, TT1, TT2, there are 11 translation techniques employed in translating the advicegiving utterance. The techniques are displayed in Table III below.

TABLE III. FREQUENCY OF TRANSLATION TECHNIQUES IN EACH TARGET TEXT

\begin{tabular}{|l|r|r|r|r|}
\hline \multirow{2}{*}{ Translation Technique } & \multicolumn{2}{|c|}{ TT1 } & \multicolumn{2}{c|}{ TT2 } \\
\cline { 2 - 5 } & Freq & \multicolumn{1}{c|}{$\%$} & \multicolumn{1}{c|}{ Freq } & \multicolumn{1}{c|}{$\%$} \\
\hline Established equivalent & 28 & 52.83 & 33 & 64.71 \\
\hline Variation & 7 & 13.21 & 7 & 13.73 \\
\hline Literal & 3 & 5.66 & 3 & 5.88 \\
\hline Explicitation & 3 & 5.66 & 1 & 1.96 \\
\hline Reduction & 3 & 5.66 & 1 & 1.96 \\
\hline Borrowing & 2 & 3.77 & 2 & 3.92 \\
\hline Transposition & 2 & 3.77 & 2 & 3.92 \\
\hline Modulation & 2 & 3.77 & - & - \\
\hline Addition & 1 & 1.89 & 1 & 1.96 \\
\hline Implicitation & 1 & 1.89 & 1 & 1.96 \\
\hline Compensation & 1 & 1.89 & - & - \\
\hline & 53 & 100 & 51 & 100 \\
\hline
\end{tabular}

Table III shows that the translators tend to employ established equivalent technique in translating advises. Compensation is the technique that only found in TT1. The example below shows how the translation techniques implemented in the target texts.

The example below was the utterance of advice made by William Pickering to Rachel Sexton.

Example 5/ST:24/TT1:21/TT2:23/SS-RS

ST : “..., I strongly advise that you decline the President's request for a meeting." (32)

TT1 : "..., aku menyarankan agar kau menolak permintaan Presiden untuk bertemu." (3132)

BT1 : ..., I suggest that you decline the President's request for a meeting.
TT2 : ".., sangat ku sarankan agar engkau menolak permintaan Presiden untuk bertemu." (35)

BT2 : ..., I strongly suggest that you decline the President's request for a meeting.

This advice is told by WP to RS to decline the president's request. WP reminds $\mathrm{RS}$ about the conflict of interest potential since her father is also a president candidate. The advice is marked by exaggeration "strongly" to show his attention to his staff (positive politeness). In TT1 the politeness marker "strongly" as positive marker is reduced. Meanwhile In TT2 the marker is maintained by translating it into "sangat".

Moreover, in both translations the pronoun "I" is translated literally into " $a k u$ " or " $k u$ " which has informal sense for officialdom. Indonesian has some pronouns for first singular that has different function based on $\mathrm{P}$ and $\mathrm{D}$, such as, "saya"for formal situation, " $a k u$ " for informal and close relation (Hassall, 2013; Ardi, Nababan, Djatmika, \& Santosa, 2018).

The sixth example is the translation of the utterance of advice given by Sedgewick Sexton to his daughter Rachel Sexton.

\section{Example 6/ST:24/TT1:21/TT2:23/SS-RS \\ ST : :You'd do well to learn some poise." (24) \\ TT1 : "Kau betul-betul harus belajar bersikap lebih baik." (21) \\ BT : You really must learn some poise \\ TT2 : "Sebaiknya kau belajar mengendalikan diri." $\underline{(23)}$ \\ BT : It is better for you to learn control yourself.}

In TT1 the illocution and the rank of imposition are maintained by the application of explicitation techniques to the politeness marker "would" into "betul-betul harus" (really must) that equal to "would" to show high obligatory. Actually "must" show domination of the speaker if it is compared to "would". Meanwhile, in TT2 the politeness marker "would" as a high obligatory marker was modulated into "sebaiknya" (it is better) that has lower obligatory (Leech, 2014, pp. 148-149).

\section{The Impact of Translation Techniques to Advice}

There are some impacts of the translation techniques to the Advice in the novel. Firstly, based on the analysis of illocution of the utterances, it is found that one of the advices is changed into suggestion (see Example 5). The shift of the illocution is caused by modulation technique. Table IV shows that the distribution of utterances in the source text (ST) and in the target texts (TT).

TABLE IV. Distribution of Advice UtTerances in Source TeXt AND THE TRANSLATIONS

\begin{tabular}{|c|l|l|l|l|l|l|l|l|}
\hline Text & GA & MjT & RS & SS & MT & WP & ZH & Total \\
\hline ST & - & - & - & 7 & - & 3 & - & 10 \\
\hline TT1 & - & - & - & 7 & - & 2 & - & 9 \\
\hline TT2 & - & - & - & 7 & - & 2 & - & 9 \\
\hline
\end{tabular}


In the ST there are ten utterances of advices but they are reduced into nine in the both TTs. It is caused by the changes of the illocution of the utterance in the target language.

The second, it is found that there is a change of imposition. In Example 6 the imposition of the utterance is changed into lower imposition in TT2 since the translator modulate "you'd do" into "sebaiknya" (It is better). Table IV below show the distribution of advice illocution in ST, TT1, and TT2.

The third was the change of politeness strategies. It can be seen in Example 5, TT1. The positive marker is reduced that cause the translation do not show exaggeration as Mitigation. There some researchers who found this phenomena (Pratama, 2014; Mubin, 2015).

The last is the change of distance. It can be seen in the translation of pronoun in Example 5. It is in formal situation between director and officer in an office. In English there are only pronoun I that can be used for all situation, meanwhile in Indonesia there are some pronouns that must be selected appropriately. The translation I into "ku" show intimate relation between RS and her director. This finding is in line with Hassall (2013) and Ardi, Nababan, Djatmika, \& Santosa, (2018).

\section{CONCLUSION}

Power, distance influence the characters who create advice due to the felicity conditions of advice. As the result, not all character can give advice. Based on this research, it can be concluded politeness markers mitigate the FTA in giving advice by showing their relation with the Hearer. It can be seen that mostly the characters use positive politeness in ST. Both translation texts also maintain the politeness strategies used by the characters. The implementation of translation technique to the politeness marker causes the changes in the translation texts. The changes are in form of illocution shift, politeness marker shift, distance shift, and imposition shift.

Translators need to maintain the ways of characters described in the novel through their utterances of advice. We suggest the translators to use established equivalent in translating politeness marker and avoid modulation since it may change the illocution and imposition of the utterances.

\section{Acknowledgment}

We would like to acknowledge the Ministry of Higher Education of Republic of Indonesia for the financial support on this research. This paper is part of the research funded by Ministry of Higher Education of Republic of Indonesia under the Doctoral Dissertation Program scheme. We also acknowledge Ms. Ingrid Brita Mathews who helped validated the data.

\section{References}

Adel, S. M., Davoudi, M., \& Ramezanzadeh, A. (2016). A qualitative study of politeness strategies used by Iranian EFL learners in a class blog. Iranian Journal of Language Teaching Research , 4 (1), 47-62.

Ardi, H., Nababan, M. R., Djatmika, \& Santosa, R. (2018). Characters' politeness strategies in giving command: Should translators keep them? 3L: The Southeast Asian Journal of English Language Studies , 24 (2), 181-193. http://doi.org/10.17576/3L-2018-2402-14.

Ardi, H., Nababan, M. R., Djatmika, \& Santosa, R. (2016b). Politeness strategies in the translation of literary works: Is it worth to evaluate? International Conference on Linguistics and Translation Studies (ICOLTS): Interlingual and intercultural communication competence (pp. 168-175). Surakarta: English Department of Faculty of Cultural Sciences of Universitas Sebelas Maret.

Ardi, H., Nababan, M. R., Djatmika, \& Santosa, R. (2016a). Politeness strategy in Indonesian translation: Has it already changed? International Seminar Prasasti III: Current research in linguistics (pp. 355-361). Surakarta: Program Studi S3 Linguistik Universitas Sebelas Maret.

Baker, M. (2018). In other words: A course book on translation (3rd Ed). New York: Routledge.

Brown, D. (2006). Deception point (titik muslihat). (I. Koesalamwardi, \& H. M. Tanaja, Trans.) Jakarta: PT. Serambi Ilmu Semesta.

Brown, D. (2001). Deception point. New York: Pocket Book Simonsays Inc.

Brown, D. (2015). Deception point. (I. D. Nimpoena, Trans.) Yogyakarta: PT. Bentang Pusaka.

Brown, P., \& Levinson, S. C. (1987). Politeness: Some universals in language usage. Cambridge: Cambridge University Press.

Chaghervand, A. E., \& Toroghpeima, G. (2015). Translation of indirect characterization in drama. The First National Conference on translation studies. Kerman: Kerman Institute of Higher Education.

Cutting, J. (2008). Pragmatic and discourse: A resource book for students. Oxon: Routledge.

DeCapua, A., \& Dunham, J. F. (1993). Strategies in the discourse of advice. Journal of Pragmatics , 20, 519-132.

Gaffney, A. L. (2015). Uncovering embedded face threat mitigation in landscape architecture critique feedback. Journal of the Scholarship of Teaching and Learning , 15 (4), 110-125. doi: 10.14434/josotl.v15i4.13456.

Hassall, T. (2013). Pragmatic development during short-term study abroad: The case of address terms in Indonesian. Journal of Pragmatics , 55, 1 17.

Kecskes, I. (2015). Intercultural impoliteness. Journal of Pragmatics , 86, 4347.

Kouper, I. (2010). The pragmatics of peer advice in a LiveJournal community. Language@Internet, 7, 1-21.

Lakoff, R. (1973). Logic of politeness, or minding your p's and q's. In C. Corum, T. C. Smith-Stark, \& A. Weiser (Ed.), Ninth Regional Meeting of Chicago Linguistic Society (pp. 292-305). Chicago: Chicago Linguistic Society.

Leech, G. (2014). The pragmatics of politeness. New York: Oxford University Press.

Machali, R. (2009). Pedoman bagi penerjemah. Bandung: Penerbit Kaifa.

Minderop, A. (2011). Metode karakterisasi telaah fiksi. Jakarta: Yayasan Obor Indonesia.

Molina, L., \& Albir, A. H. (2002). Translation techniques revisited: A dynamic and functionalist approach. Meta: Journal des Traducteurs/Meta: Translators' Journal , XLVII (4), 498-512.

Mubin, H. F. (2015). Analisis terjemahan kalimat yang mengakomodasi kesantunan tuturan menyarankan (suggesting) dalam film Argo (2012). Program Studi Magister Linguistik. Surakarta: Universitas Sebelas Maret.

Newmark, P. (1988). A textbook of translation. London: Prentice Hall.

Pratama, I. D. (2014). Analisis perbandingan strategi kesantunan tuturan memerintah dalam film 'The amazing Spiderman' dan dua versi terjemahannya (subtitle VCD dan subtitle amatir) serta dampaknya pada kualitas terjemahan. Surakarta: Pascasarjana Universitas Sebelas Maret.

Santosa, R. (2017). Metode penelitian kualitatif kebahasaan. Surakarta: UNS Press. 
Silence, E. (2013). Giving and receiving peer advice in an online breast cancer support group. Cyberpsychology, Behavior, and Social Networking , 16 (6), 480-485. DOI: 10.1089/cyber.2013.1512.

Spradley, J. P. (1980). Participant observation. New York: Holt, Rinehart and Winston.

Tretyakova, T. P. (2016). On politeness in translation. Journal of Siberian Federal University. Humanities \& Social Sciences , 3, 653-661.

Umalee, M. H. (2013). Analisis maksim kerendahan hati dalam prinsip kesantunan pada terjemahan novel 'Eclipse' karya Stephenie Meyer. Surakarta: Pascasarjana Universitas Sebelas Maret.

Zhao, W. (2009). Literary criticism and the creation of Ibsen's image in China. Perspectives: Studies in Translatology, 17 (3), 137-149. 